\title{
MANAJEMEN PENDIDIKAN KARAKTER PERSPEKTIF PENDIDIKAN AGAMA ISLAM DI SD MUHAMMADIYAH 8 BANJARMASIN
}

\author{
Latifah $^{1}$, Nelly Mariati ${ }^{2}$. \\ Email: rachel.nera@yahoo.com \\ Akademi Kebidanan Yapkesbi Banjarbaru ${ }^{1}$ \\ Universitas Muhammadiyah Banjarmasin ${ }^{2}$
}

\begin{abstract}
ABSTRAK
Pendekatan penelitian yang digunakan dalam penelitian ini adalah pendekatan penelitian kualitatif. karena penelitian ini menggunakan pendekatan kualitatif maka hasil data akan difokuskan berupa pertanyaan berupa deskriptif dan tidak mengkaji suatu hipotesa serta tidak mengkorelasi variabel. Keberadaan peneliti dalam penelitian kualitatif menonjolkan kapasitas jiwa raga dalam mengamati, bertanya, melakukan penelitian dan mengabstraksi. Hal ini lebih dipertegas lagi oleh Nasution bahwa peneliti merupakan peneliti utama. Jadi dalam penelitian ini, peneliti terjun sendiri secara langsung untuk mengadakan pengamatan atau wawancara dan terlibat langsung dalam obyek atau subyek penelitian. Disini peneliti juga akan menggambarkan penerapan-penerapan hukuman yang dilaksanakan di SD Muhammadiyah 8 Banjarmasin untuk meningkatkan disiplin santri dalam segala aspek berupa tata tertib kegiatan-kegiatan wajib yang harus diikuti oleh santri dalam menanamkan pendidikan karakter.
\end{abstract}

Kata Kunci: manajemen pendidikan karakter, perspektif Pendidikan Islam

\begin{abstract}
The research approach used in this research is a qualitative research approach. because this study uses a qualitative approach, the results of the data will be focused in the form of descriptive questions and do not examine a hypothesis and do not correlate variables. The existence of researchers in qualitative research emphasizes the mental and physical capacity of observing, asking questions, conducting research and abstracting. This is further emphasized by Nasution that the researcher is the main researcher. So in this study, the researcher went directly to conduct observations or interviews and was directly involved in the object or subject of the research. Here the researcher will also describe the punishments implemented at SD Muhammadiyah 8 Banjarmasin to improve student discipline in all aspects in the form of rules for mandatory activities that must be followed by students in instilling character education.
\end{abstract}

Keywords: character education management, Islamic education perspective 


\section{PENDAHULUAN}

Karakter berarti kualitas mental atau moral, kekuatan moral, nama atau reputasinya. Dalam pandangan Doni Koesoema karakter diasosiasikan dengan temperamen yang memberinya sebuah definisi yang menekankan unsur psikososial yang dikaitkan dengan pendidikan dan konteks lingkungan. Karakter juga dipahami dari sudut pandang behavioral yang menekankan unsur somatopsikis yang dimiliki oleh individu sejak lahir. Disini karakter dianggap sama dengan kepribadian. Kepribadian dianggap sebagai ciri atau karakteristik atau gaya, sifat khas dari diri seseorang, yang bersumber dari bentukanbentukan yang diterima dari lingkungan, misalnya pengaruh keluarga pada masa kecil dan bawaan seseorang sejak lahir.

Menurut Tadzkirotun Musfiroh karakter mengacu pada serangkaian sikap (attitude), perilaku (behaviours), motivasi (motivations) dan keterampilan (skills). Makna karakter itu sendiri sebenarnya berasal dari bahasa Yunani yang berarti to mark atau menandai dan memfokuskan pada aplikasi nilai kebaikan dalam bentuk tindakan atau tingkah laku, sehingga orang yang tidak jujur, kejam, rakus dan berprilaku jelek dikatakan sebagai orang yang berkarakter jelek. Sebaliknya orang yang berprilaku sesuai dengan kaidah moral dinamakan berkarakter mulia.

Sedangkan pesantren berasal dari kata santri, dengan awalan pe, dan akhiran an yang berarti tempat tinggal santri. Soegarda Poerbakawatja, yang dikutip oleh Haidar Putra Daulay mengatakan pesantren berasal dari kata santri yaitu seseorang yang belajar agama Islam, sehingga dengan demikian pesantren mempunyai arti tempat orang berkumpul untuk belajar agama Islam. Ada juga yang mengartikan pesantren sebagai lembaga pendidikan Islam Indonesia yang bersifat "tradisional" untuk mendalami ilmu tentang agama Islam dan mengamalkan sebagai pedoman hidup keseharian.
Asal usul "santri" dalam pandangan Nurcholish Madjid dapat dilihat dari dua pendapat. Pertama, pendapat yang mengatakan bahwa "santri" berasal dari perkataan "sastri", sebuah kata dari bahasa Sanskerta yang artinya melek huruf. Disisis lain, Zamkhsyari Dhofier berpendapat bahwa, kata "santri" dalam India berarti orang yang tahu buku-buku suci agama Hindu, atau seorang sarjana ahli kitab suci agama Hindu. Atau secara umum dapat diartikan bukubuku suci, buku-buku agama, atau buku-buku tentang ilmu pengetahuan. Kedua, pendapat yang mengatakan bahwa perkataan santri sesungguhnya berasal dari bahasa Jawa, yaitu dari kata"cantrik", berartiseseorang yang selalu mengikuti seorang guru kemana guru itu pergi menetap.

Dalam pemakaian sehari-hari, istilah pesantren bisa disebut dengan pondok saja atau kedua kata ini digabung menjadi pondok pesantren. Secara esensial, semua istilah ini mengandung makna yang sam, kecuali sedikit perbedaan. Asrama yang menjadi penginapan santri sehari-hari dapat dipandang sebagai pembeda antara pondok dan pesantren. Kata "pondok" berasal dari bahasa Arab yang berarti funduq artinya tempat menginap (asrama). Dinamakan demikian kerena pondok merupakan tempat penampungan sederhana bagi para pelajar yang jauh dari tempat asalnya.

M. Arifin menyatakan bahwa, penggunaan gabungan kedua istilah secara integral yakni pondok dan pesantren menjadi pondok pesantren lebih mengakomoddasi karakter keduanya. Pondok pesantren lebih mengakomodasi karakter keduanya. Pondok pesantren menurutnya, "Suatu lembaga pendidikan agama Islam yang tumbuh serta diakui masyarakat sekitar, dengan sistem asrama (komplek) dimana santri-santri menerima pendidikan agama melalui sistem pengajian atau madrasah yang sepenuhnya berada dibawah kedaulatan dari leadership seorang atau beberapa 
orang kyai dengan ciri-ciri khas yang bersifat karismatik serta independen dalam segala hal".

Dalam kamus besar bahasa Indonesia pesantren diartikan sebagai asrama tempat santri atau tempat murid-murid belajar mengaji. Sedangkan secara isttilah pesantren adalah lembaga pendidikan Islam dimana para santri biasa tinggal di pondok (asrama) dengan materi pengajaran kitab-kitab klasik dan kitab-kitab umum bertujuan untuk menguasai ilmu agama Islam secara detail serta mengamalkan sebagai pedoman hidup keseharian dengan menekankan penting moral dalam kehidupan bermasyarakat.

\section{METODE PENELITIAN}

Pendekatan penelitian yang digunakan dalam penelitian ini adalah pendekatan penelitian kualitatif. karena penelitian ini menggunakan pendekatan kualitatif maka hasil data akan difokuskan berupa pertanyaan berupa deskriptif dan tidak mengkaji suatu hipotesa serta tidak mengkorelasi variabel. Keberadaan peneliti dalam penelitian kualitatif menonjolkan kapasitas jiwa raga dalam mengamati, bertanya, melakukan penelitian dan mengabstraksi. Hal ini lebih dipertegas lagi oleh Nasution bahwa peneliti merupakan peneliti utama. Jadi dalam penelitian ini, peneliti terjun sendiri secara langsung untuk mengadakan pengamatan atau wawancara dan terlibat langsung dalam obyek atau subyek penelitian. Disini peneliti juga akan menggambarkan penerapan-penerapan hukuman yang dilaksanakan di SD Muhammadiyah 8 Banjarmasin untuk meningkatkan disiplin santri dalam segala aspek berupa tata tertib kegiatankegiatan wajib yang harus diikuti oleh santri dalam menanamkan pendidikan karakter.

PEMBAHASAN DAN HASIL

Dasar Pendidikan Karakter dan Landasan Hukum di Indonesia

1. Dasar pendidikan karakter
Dalam Islam, tidak ada disiplin ilmu yang terpisah dari etika-etika Islam. Sebagai usaha yang identik dengan ajaran agama, pendidikan karakter dalam Islam memiliki keunikan dan perbedaan dengan pendidikan karakter di dunia barat. Perbedaan-perbedaan tersebut mencakup penekanan terhadap prinsip-prinsip agama yang abadi, aturan dan hukum dalam memperkuat moralitas, perbedaan pemahaman tentang kebenaran, penolakan terhadap otonomi moral sebagai tujuan pendidikan moral, dan penekanan pahala di akhirat sebagai motivasi perilaku bermoral.

Inti dari perbedaaan-perbedaan ini adalah keberadaan wahyu ilahi sebagai sumber dan rambu-rambu pendidikan karakter dalam islam. Akibatnya, pendidika karakter dalam Islam lebih sering dilakukan dengan cara doktriner dan dogmatis, tidak secara demokratis dan logis.

Implementasi pendidikan karakter dalam Islam, tersimpul dalam karakter pribadi Rasulullah SAW. Dalam pribadi Rasul, tersemai nilai-nilai akhlak yang mulia dan agung. Al-qur'an dalam surat Al-ahzab ayat 21 mengatakan:

Artinya: "Sesungguhnya Telah ada pada (diri) Rasulullah itu suri teladan yang baik bagimu (yaitu) bagi orang yang mengharap (rahmat) Allah dan (kedatangan) hari kiamat dan dia banyak menyebut Allah".

Karakter atau Akhlak tidak diragukan lagi memiliki peran besar dalam kehidupan manusia. Menghadapi fenomena krisis moral, tuduhan seringkali diarahkan kepada dunia pendidikan sebagai penyebabnya. Hal ini dikarenakan pendidikan berada pada barisan terdepan dalam menyiapkan sumber daya manusia yang berkualitas, dan secara moral memang harus berbuat demikian. ${ }^{[10]}$ Pembinaan karakter dimualai dari 
individu, karena pada hakikatnya karakter itu memang individual, meskipun ia dapat berlaku dalam konteks yang tidak individual. Karenanya pembinaan karakter dimulai dari gerakan individual, yang kemudian diproyeksikan menyebar ke individu-idividu lainnya, lalu setelah jumlah individu yang tercerahkan secara karakter atau akhlak menjadi banyak, maka dengan sendirinya akan mewarnai masyarakat. Pembinaan karakter selanjutnya dilakukan dalam lingkungan keluarga dan harus dilakukan sedini mungkin sehingga mempengaruhi pertumbuhan dan perkembangan anak. Melalui pembinaan karakter pada setiap individu dan keluarga akan tercipta peradaban masyarakat yang tentram dan sejahtera.

Hal ini dapat dipahami bahwa ajaran Islam serta pendidikan karakter mulia yang harus diteladani agar manusia yang hidup sesuai denga tuntunan syari'at. Sesungguhnya Rasulullah adalah contoh serta teladan bagi umat manusia yang mengajarkan serta menanamkan nilai-nilai karakter yang mulia kepada umatnya. Sebaik-baik manusia adalah yang baik karakter atau akhlaknya dan manusia yang sempurna adalah yang memiliki akhlak al-karimah, karena ia merupakan cerminan iman yang sempurna.

2. Landasan Pendidikan Karakter di Indonesia

Untuk mendukung perwujudan citacita pembangunan karakter sebagaimana diamanatkan dalam Pancasila dan Pembukaan UUD 1945 serta mengatasi permasalahan kebangsaan saat ini, maka Pemerintah menjadikan pembangunan karakter sebagai salah satu program prioritas pembangunan nasional. Semangat itu telah ditegaskan dalam Rencana Pembangunan Jangka Panjang Nasional (RPJPN) tahun 2005-2025, di mana pendidikan karakter ditempatkan sebagai landasan untuk mewujudkan visi pembangunan nasional, yaitu "mewujudkan masyarakat berakhlak mulia, bermoral, beretika, berbudaya, dan beradab berdasarkan falsafah Pancasila"

Terkait dengan upaya mewujudkan pendidikan karakter sebagaimana yang diamanatkan dalam RPJPN, sesungguhnya hal tersebut sudah tertuang pada fungsi dan tujuan pendidikan nasional, yaitu "Pendidikan nasional berfungsi mengembangkan dan membentuk watak serta peradaban bangsa yang bermartabat dalam rangka mencerdaskan kehidupan bangsa, bertujuan untuk berkembangnya potensi peserta didik agar menjadi manusia yang beriman dan bertakwa kepada Tuhan Yang Maha Esa, berakhlak mulia, sehat, berilmu, cakap, kreatif, mandiri, dan menjadi warga negara yang demokratis serta bertanggung jawab" (Undang-Undang Republik Indonesia Nomor 20 Tahun 2003 tentang Sistem Pendidikan Nasional (UUSPN)). Dengan demikian, RPJPN dan UUSPN merupakan landasan yang kokoh untuk melaksanakan secara operasional pendidikan karakter sebagai prioritas program Kementerian Pendidikan Nasional 2010-2014, sebagaimana yang tertuang dalam Rencana Aksi Nasional Pendidikan Karakter (2010). Isi dari rencana aksi tersebut adalah bahwa "pendidikan karakter disebutkan sebagai pendidikan nilai, pendidikan budi pekerti, pendidikan moral, pendidikan watak yang bertujuan mengembangkan kemampuan peserta didik untuk memberikan keputusan baik-buruk, memelihara apa yang baik dan mewujudkan kebaikan itu dalam kehidupan sehari-hari dengan sepenuh hati”.

Sementara itu, dalam INPRES No. 1 Tahun 2010 disebutkan "penyempurnaan kurikulum dan metode pembelajaran aktif berdasarkan nilai nilai budaya bangsa untuk membentuk daya saing dan karakter bangsa". 
Di lain sisi, dalam latar belakang UUSPN Pasal 3 menyebutkan bahwa "Pendidikan Nasional berfungsi mengembangkan kemampuan dan membentuk karakter serta peradaban bangsa yang bermartabat dalam rangka mencerdaskan kehidupan bangsa".

Atas dasar itu, pendidikan karakter bukan sekedar mengajarkan mana yang benar dan mana yang salah, lebih dari itu, pendidikan karakter menanamkan kebiasaan (habituation) tentang hal mana yang baik sehingga peserta didik menjadi paham (kognitif) tentang mana yang benar dan salah, mampu merasakan (afektif) nilai yang baik dan biasa melakukannya (psikomotor). Dengan kata lain, pendidikan karakter yang baik harus melibatkan bukan saja aspek "pengetahuan yang baik (moral knowing), akan tetapi juga "merasakan dengan baik atau loving good (moral feeling), dan perilaku yang baik (moral action). Pendidikan karakter menekankan pada habit atau kebiasaan yang terus-menerus dipraktikkan dan dilakukan. Dengan demikian, jelaslah sudah landasan dan alasan penerapan pendidikan karakter di Indonesia.

\section{Unsur-Unsur Pendidikan Karakter}

Ada beberapa dimensi manusia yang secara psikologis dan sosiologis perlu dibahas dalam kaitannya dengan terbentuknya karakter pada diri manusia. adapun unsur-unsur tersebut adalah sikap, emosi, kemauan, kepercayaan dan kebiasaan

Sikap seseorang akan dilihat orang lain dan sikap itu akan membuat orang lain menilai bagaimanakah karakter orang tersebut, demikian juga halnya emosi, kemauan, kepercayaan dan kebiasaan, dan juga konsep diri (Self Conception).

1. Sikap

Sikap seseorang biasanya adalah merupakan bagian karakternya, bahkan dianggap sebagai cerminan karakter seseorang tersebut. Tentu saja tidak sepenuhnya benar, tetapi dalam hal tertentu sikap seseorang terhadap sesuatu yang ada dihadapannya menunjukkan bagaimana karakternya.

2. Emosi

Emosi adalah gejala dinamis dalam situasi yang dirasakan manusia, yang disertai dengan efeknya pada kesadaran, perilaku, dan juga merupakan proses fisiologis.

3. Kepercayaan

Kepercayaan merupakan komponen kognitif manusia dari faktor sosiopsikologis. Kepercayaan bahwa sesuatu itu "benar" atau "salah" atas dasar bukti, sugesti otoritas, pengalaman, dan intuisi sangatlah penting untuk membangun watak dan karakter manusia. jadi, kepercayaan itu memperkukuh eksistensi diri dan memperkukuh hubungan denga orang lain.

4. Kebiasaan dan Kemauan

Kebiasaan adalah komponen konatif dari faktor sosiopsikologis. Kebiasaan adalah aspek perilaku manusia yang menetap, berlangsung secara otomatis, dan tidak direncanakan. Sementara itu, kemauan merupakan kondisi yang sangat mencerminkan karakter seseorang. Ada orang yang kemauannya keras, yang kadang ingin mengalahkan kebiasaan, tetapi juga ada orang yang kemauannya lemah. Kemauan erat berkaitan dengan tindakan, bahakan ada yag mendefinisikan kemauan sebagai tindakan yang merupakan usaha seseorang untuk mencapai tujuan.

5. Konsep diri (Self Conception)

Hal penting lainnya yang berkaitan dengan (pembangunan) karakter adalah konsep diri. Proses konsepsi diri merupakan proses totalitas, baik sadar maupun tidak sadar, tentang bagaimana karakter dan diri kita dibentuk. Dalam proses konsepsi diri, biasanya kita mengenal diri kita dengan mengenal orang 
lain terlebih dahulu. Citra diri dari orang lain terhadap kita juga akan memotivasi kita untuk bangkit membangun karakter yang lebih bagus sesuai dengan citra. Karena pada dasarnya citra positif terhadap diri kita, baik dari kita maupun dari orang lain itu sangatlah berguna.

\section{Arah dan Metode Pendidikan Karakter dalam Perspektif Pendidikan Agama Islam}

Pendidikan karakter seharusnya berangkat dari konsep dasar manusia: fitrah. Setiap anak dilahirkan menurut fitrahnya, yaitu memiliki akal, nafsu (jasad), hati dan ruh. Konsep inilah yang sekarang lantas dikembangkan menjadi konsep multiple intelligence. Dalam Islam terdapat beberapa istilah yang sangat tepat digunakan sebagai pendekatan pembelajaran. Konsep-konsep itu antara lain: tilâwah, ta'lîm', tarbiyah,

ta'dîb,

tazkiyah dan tadlrîb Tilâwah menyangkut

kemampuan membaca; ta'lim terkait dengan pengembangan kecerdasan intelektual (intellectual quotient); tarbiyah menyangkut kepedulian dan kasih sayang secara naluriah yang didalamnya ada asah, asih dan asuh; ta'dîb terkait dengan pengembangan kecerdasan emosional (emotional quotient); tazkiyah terkait dengan pengembangan kecerdasan spiritual (spiritual quotient); dan tadlrib terkait dengan kecerdasan fisik atau keterampilan (physical quotient atau adversity quotient).

Gambaran di atas menunjukkan metode pembelajaran yang menyeluruh dan terintegrasi. Pendidik yang hakiki adalah Allah, guru adalah penyalur hikmah dan berkah dari Allah kepada anak didik. Tujuannya adalah agar anak didik mengenal dan bertaqwa kepada Allah, dan mengenal fitrahnya sendiri. Pendidikan adalah bantuan untuk menyadarkan, membangkitkan, menumbuhkan, memampukan dan memberdayakan anak didik akan potensi fitrahnya.
Untuk mengembangkan kemampuan membaca, dikembangkan metode tilawah tujuannya agar anak memiliki kefasihan berbicara dan kepekaan dalam melihat fenomena. Untuk mengembangkan potensi fitrah berupa akal dikembangkan metode ta'lîm, yaitu sebuah metode pendidikan ilmu pengetahuan dan teknologi yang menekankan pada pengembangan aspek kognitif melalui pengajaran. Dalam pendidikan akal ini sasarannya adalah terbentuknya anak didik yang memiliki pemikiran jauh ke depan, kreatif dan inovatif. Sedangkan output-nya adalah anak yang memiliki sikap ilmiah, ulûl albâb dan mujtahid. Ulul Albab adalah orang yang mampu mendayagunakan potensi pikir (kecerdasan intelektual/IQ) dan potensidzikirnya untuk memahami fenomena ciptaan Tuhan dan dapat mendayagunakannya untuk kepentingan kemanusiaan. Sedangkan mujtahid adalah orang mampu memecahkan persoalan dengan kemampuan intelektualnya. Hasilnya yaitu ijtihad (tindakannya) dapat berupa ilmu pengetahuan maupun teknologi. Outcome dari pendidikan akal (IQ) terbentuknya anak yang saleh (waladun shalih).

Pendayagunaan potensi pikir dan zikir yang didasari rasa iman pada gilirannya akan melahirkan kecerdasan spiritual (spiritual quotient/SQ). Dan kemampuan mengaktualisasikan kecerdasan spiritual inilah yang memberikan kekuatan kepada guru dan siswa untuk meraih prestasi yang tinggi.

Metode tarbiyah digunakan untuk membangkitkan rasa kasih sayang, kepedulian dan empati dalam hubungan interpersonal antara guru dengan murid, sesama guru dan sesama siswa. Implementasi metode tarbiyah dalam pembelajaran mengharuskan seorang guru bukan hanya sebagai pengajar atau guru mata pelajaran, melainkan seorang bapak atau ibu yang memiliki kepedulian dan hubungan interpersonal yang baik 
dengan siswa-siswinya. Kepedulian guru untuk menemukan dan memecahkan persoalan yang dihadapi siswanya adalah bagian dari penerapan metode tarbiyah.

Metode $t a$ 'dîb digunakan

untuk membangkitkan "raksasa tidur", kalbu (EQ) dalam diri anak didik. Ta'dîb lebih berfungsi pada pendidikan nilai dan pengembangan iman dan taqwa. Dalam pendidikan kalbu ini, sasarannya adalah terbentuknya anak didik yang memiliki komitmen moral dan etika. Sedangkan out put-nya adalah anak yang memiliki karakter, integritas dan menjadi mujaddid. Mujaddid adalah orang yang memiliki komitmen moral dan etis dan rasa terpanggil untuk memperbaiki kondisi masyarakatnya. Dalam hal mujaddid ini Abdul Jalil (2004) mengatakan: "Banyak orang pintar tetapi tidak menjadi pembaharu (mujaddid). Seorang pembaharu itu berat resikonya. Menjadi pembaharu itu karena panggilan hatinya, bukan karena kedudukan atau jabatannya”.

Metode tazkiyah digunakan

untuk membersihkan jiwa (SQ). Tazkiyah lebih berfungsi untuk mensucikan jiwa dan mengembangkan spiritualitas. Dalam pendidikan Jiwa sasarannya adalah terbentuknya jiwa yang suci, jernih (bening) dan damai (bahagia). Sedang output-nya adalah terbentuknya jiwa yang tenang (nafs al-mutmainnah), ulûl arhâm dan tazkiyah. Ulûl arhâm adalah orang yang memiliki kemampuan jiwa untuk mengasihi dan menyayangi sesama sebagai manifestasi perasaan yang mendalam akan kasih sayang Tuhan terhadap semua hambaNya. Tazkiyah adalah tindakan yang senantiasa mensucikan jiwanya dari debu-debu maksiat dosa dan tindakan sia-sia (kedlaliman).

Metode tadlrîb (latihan) digunakan untuk mengembangkan keterampilan fisik, psikomotorik dan kesehatan fisik. Sasaran (goal) dari tadlrîb adalah terbentuknya fisik yang kuat, cekatan dan terampil. Output-nya adalah terbentuknya anaknya yang mampu bekerja keras, pejuang yang ulet, tangguh dan seorang mujahid. Mujahid adalah orang yang mampu memobilisasi sumber dayanya untuk mencapai tujuan tertentu dengan kekuatan, kecepatan dan hasil maksimal.

Sebenarnya metode pembelajaran yang digunakan di sekolah lebih banyak dan lebih bervariasi yang tidak mungkin semua dikemukakan di sini secara detail. Akan tetapi pesan yang hendak dikemukakan di sini adalah bahwa pemakaian metode pembelajaran tersebut adalah suatu bentuk "mission screed" yaitu sebagai penyalur hikmah, penebar rahmat Tuhan kepada anak didik agar menjadi anak yang saleh. Semua pendekatan dan metode pendidikan dan pengajaran (pembelajaran) haruslah mengacu pada tujuan akhir pendidikan yaitu terbentuknya anak yang berkarakter taqwa dan berakhlak budi pekerti yang luhur. Metode pembelajaran dikatakan mengemban misi suci karena metode sama pentingnya dengan substansi dan tujuan pembelajaran itu sendiri.

\section{KESIMPULAN}

Kesimpulan dalam penelitian ini bertujuan dari pendidikan karakter dalam perspektif pendidikan agama Islam di Indonesia itu adalah: pertama, supaya seseorang terbiasa melakukan perbuatan baik. Kedua, supaya interaksi manusia dengan Allah SWT dan sesama makhluk lainnya senantiasa terpelihara dengan baik dan harmonis. Esensinya sudah tentu untuk memperoleh yang baik, seseorang harus membandingkannya dengan yang buruk atau membedakan keduanya. Kemudian setelah itu, dapat mengambil kesimpulan dan memilih yang baik tersebut dengan meninggalkan yang buruk. Dengan karakter yang baik maka kita akan disegani orang. Sebaliknya, seseorang dianggap tidak ada, meskipun masih hidup, kalau akhlak atau karakternya rusak. Meskipun dalam 
pelaksanaannya, tujuan dari pendidikan karakter itu sendiri dapat dicapai apabila pendidikan karakter dilakukan secara benar dan menggunakan media yang tepat. Pendidikan karakter dilakukan setidaknya melalui berbagai media, yang di antarnya mencakup keluarga, satuan pendidikan, masyarakat sipil, masyarakat politik, pemerintah, dunia usaha dan media massa.

\section{DAFTAR PUSTAKA}

Agus Wibowo. 2013. Manajemen Pendidikan Karakter di Sekolah (Konsep dan Praktik Implementasi). (Cetakan Pertama Februari, Diterbitkan oleh: Pustaka Pelajar, Yogyakarta).

Alexandar Ramadoss \& Gopalsamy Poyya Moli, 2011. Biodiversity Conservation through Environmental Education for Sustainable Development A Case Study from Puducherry, India. International Electronic Journal of

Aziza Meria, 2012. Pendidikan Islam di Era Globalisasi dalam Membangun Karakter Bangsa. (Jurnal Al Ta'lim Jilid 1 Nomor 1 Februari 2012), 87

Budi Sri Hastuti, Pendidikan Untuk Pengembangan Berkelanjutan (Education for Sustainable Development) dalam Perspektif PNFI Implementasi EFSD pada program PNFI. Andragogia - Jurnal PNFI / Volume 1 / No 1 - Nopember 2009. 46-47

Dwiyanto Joko Pranowo, Implementasi Pendidikan Karakter Kepedulian dan Kerja Sama pada Mata Kuliah Keterampilan Berbicara Bahasa Prancis dengan Metode Bermain Peran, Jurnal Pendidikan Karakter, Tahun III, Nomor 2, Juni 2013, 220

Hairuddin, Pendidikan Karakter Berbasis Sunnah Nabi. (Jurnal Al Ulum, Jurnal Studi Islam IAIN GorontaloVolume 13 Nomor 1 Tahun 2013, ISSN: 1412-0534), 168

Imam Syafi'I, Pendidikan Karakter: Sebuah Pemikiran Syaikh Az-Zarnujy dalam Penerapan Kurikulum 2013. Volume 5, Nomor 1, Januari 2014, 9

Luk Luk Nur Mufidah. Pemikiran Gus Dur Tentang Pendidikan Karakter dan Kearifan
Lokal. Al Tahrir, Vol. 15, No. 1 Mei 2015: 91-100, hlm. 94

Muh Musafa', Kurikulum Pendidikan Agama Islam Berwawasan Lingkungan Hidup (Skripsi), (Yogyakarta: IAIN Sunan Kalijaga, 2003), 91

Muhaimin, 2009. Rekonstruksi

Pendidikan Islam (Dari

Paradigma Pengembangan, Manajemen Kelembagaan, Kurikulum Hingga Strategi Pembelajaran). (Jakarta: Rajawali Press, ISBN: 978-979-769-260-5), 127

Nur Ainiyah, Pembentukan Karakter Melalui Pendidikan Agama Islam. Jurnal Al-Ulum (Jurnal Studi-Studi Islam) IAIN Gorontalo, ISSN 1412-0534. Volume. 13 Nomor 1, Juni 2013, 28

Ngalimun dan Yusuf Rohmadi. 2021. Harun Nasution: sebuah pemikiran pendidikan dan relevansinya dengan dunia pendidikan kontemporer. Jurnal Terapung: Ilmu-Ilmu Sosial. eISSN: 2656-2928. Volume 3. Nomor 2 September 2021. https://ojs.uniskabjm.ac.id/index.php/terapung/article/vie w/6016

Patimah. Pendidikan Karakter Melalui Program Ekstrakurikuler. Pembinaan Pendidikan Karakter Sekolah Menengah Pertama, Bagian IV Pendidikan Karakter Melalui Ekstrakurikuler, BAB I Pengertian Pendidikan Karakter Melalui Ekstrakurikuler. Publish: 18-10-2011, 23:12:06. 1

Rifqi Afandi, Intergrasi Pendidikan Karakter Dalam Pembelajaran IPS disekolah Dasar.(Dosen Fakultas Keguruan dan Ilmu Pendidikan Universitas Muhammadiyah Sidoarjo). PEDAGOGIA, Vol. 1, No. 1, Desember 2011.88

Zainuddin, Paradigma Pendidikan Terpadu; Menyiapkan Generasi Ulul Albab, (Malang: UIN Malang Press, 2010), h. 8182 dalam Rakhmawati. Pendidikan Karakter Perspektif Pendidikan Islam. Jurnal Al-Ulum (Jurnal Studi-Studi Islam) IAIN Gorontalo Pendidikan Karakter Perspektif Pendidikan Islam. ISSN 14120534. Volume. 13 Nomor 1, Juni 2013, 194. 